\title{
PENURUNAN KADAR AMONIA, NITRIT, DAN NITRAT LIMBAH CAIR INDUSTRI TAHU MENGGUNAKAN ARANG AKTIF DARI AMPAS KOPI
}

\author{
Irmanto, Suyata \\ Program Studi Kimia, Jurusan MIPA Fakultas Sains dan Teknik UNSOED, Purwokerto
}

\begin{abstract}
The tofu industry is one of food industry which the product of organic waste to environment pollution. One of alternative methode which used to overcome tofu industrial waste water pollution is adsorption methode using activated carbon from coffee waste. The aim of this researched is to know about the activated carbon from coffee waste quality which observe of rendemen, water content, ash content, and iodium adsorption, to know optimum contact of time and $\mathrm{pH}$ of coffee waste to decrease ammonia, nitrite and nitrate contents in tofu industry waste water and to know decrease percentage of ammonia, nitrite and nitrate contents in tofu industrial waste water using activated carbon from coffee waste. The activated carbon made by soaking of coffee waste in $\mathrm{HCl} 0.1 \mathrm{M}$ solution for 2 days. The activated carbon coaled in muffle furnace at temperature $350^{\circ} \mathrm{C}$. The activated carbon analyzed consist of rendemen, water content, ash content, and iodium adsorption. Optimum contact of time and $\mathrm{pH}$ of coffee waste determined in order to get optimum adsorption ammonia, nitrite and nitrate in tofu industrial waste water. Contact time variation are $1,10,30,45,60,90,120$ minutes and $\mathrm{pH}$ variation are 4, 5, 6, 7, 8, 9, 10. The result showed that the activated carbon from coffee waste fulfill the criteria SNI number 06-3730-1995. The activated carbon from coffee waste could be used to decrease the ammonia, nitrite, and nitrate contents in tofu industrial waste water at the optimum contact of time of 30 minutes and $\mathrm{pH} 7$. Decreasing percentage of ammonia, nitrite and nitrate contents in tofu industrial waste water are $64,69 \%, 52,35 \%$ and $86,40 \%$ respectively.
\end{abstract}

Keywords : ammonia, nitrite, nitrate, tofu industry wastewater

\section{PENDAHULUAN}

Salah satu limbah industri yang berpotensi mencemari lingkungan yaitu limbah cair industri tahu. Limbah cair industri tahu mengandung sejumlah besar karbohidrat, lemak dan protein. Molekul organik yang terdapat dalam limbah cair industri tahu secara garis besar mengalami perombakan terutama karbohidrat, lemak dan protein yang terkandung didalamnya yang dilakukan oleh mikroorganisme pengurai. Bahan organik kompleks berupa karbohidrat, lemak dan protein mula-mula diubah menjadi bentuk persenyawaan yang lebih sederhana glukosa, gliserol, asam lemak dan asam amino. Asam amino yang merupakan hasil dari perombakan protein akan dioksidasi menjadi nitrogen amonia $\left(\mathrm{NH}_{3}\right)$ dan senyawa karboksil. Senyawa $\left(\mathrm{NH}_{3}\right)$ akan dioksidasi lagi menjadi nitrit $\left(\mathrm{NO}_{2}{ }^{-}\right)$. Apabila oksigen tersedia akan dioksidasi lagi menjadi nitrat $\left(\mathrm{NO}_{3}{ }^{-}\right)$ (Pelczar dan Chan, 1996). Bahan organik yang terdapat pada limbah cair industri tahu apabila berada dalam konsentrasi tinggi dan langsung dibuang tanpa pengolahan akan menimbulkan pencemaran pada lingkungan perairan (Nurhasan dan Pramudyanto, 1997). 
Tabel 1. Karakteristik Limbah Cair Industri Tahu

\begin{tabular}{lll}
\hline No. & $\begin{array}{c}\text { Karakteristik } \\
\text { Fisik dan Kimia } \\
\text { Limbah Tahu }\end{array}$ & \multicolumn{1}{c}{ Nilai } \\
\hline 1 & Padatan Terendap & $170-190 \mathrm{mg} / \mathrm{L}$ \\
2 & Padatan & $638-660 \mathrm{mg} / \mathrm{L}$ \\
& Tersuspensi & \\
3 & Padatan Total & $668-703 \mathrm{mg} / \mathrm{L}$ \\
4 & Warna & $2225-250 \mathrm{pt} \mathrm{Co}$ \\
5 & Kekeruhan & $524-585 \mathrm{FTU}$ \\
6 & Amoniak-Nitrogen & $23,3-23,5 \mathrm{mg} / \mathrm{L}$ \\
7 & Nitrit-Nitrogen & $0,1-0,5 \mathrm{mg} / \mathrm{L}$ \\
8 & Nitrat-Nitrogen & $3,5-4,0 \mathrm{mg} / \mathrm{L}$ \\
9 & PH & $4-6$ \\
10 & BOD & $6000-8000 \mathrm{mg} / \mathrm{L}$ \\
11 & COD & $7500-14000$ \\
& & $\mathrm{mg} / \mathrm{L}$ \\
12 & Abu & $0,19 \%$ \\
13 & Protein & $0,08 \%$ \\
14 & Karbohidrat & $0,51 \%$ \\
15 & Pati & $0,46 \%$ \\
\hline Sim &
\end{tabular}

Sumber : Nurhasan dan Pramudyanto (1997)

Kandungan nitrogen serta unsur hara lain pada konsentrasi tinggi di dalam air akan mempercepat pertumbuhan tumbuhan air. Kondisi demikian lambat laun akan menyebabkan kematian biota dalam air (Bahri, 2006). Limbah cair industri tahu juga dapat mengakibatkan berbagai penyakit pada manusia. Dalam tubuh manusia, senyawa nitrogen menimbulkan efek toksik apabila senyawa tersebut berada dalam bentuk nitrit. Efek toksik yang ditimbulkan oleh nitrit adalah methemoglobin, yaitu merupakan penghambatan terhadap pengangkutan oksigen di dalam aliran darah. Jika jumlah methemoglobin lebih dari $15 \%$ dari total hemoglobin maka akan terjadi suatu keadaan yang disebut sianosis. Sianosis merupakan suatu keadaan dimana seluruh jaringan manusia kekurangan oksigen.

Metode penanganan limbah berkembang sangat pesat. Salah satunya adalah dengan mengurangi kadar zat-zat yang berbahaya seperti amonia, nitrit dan nitrat yang terdapat dalam limbah cair industri tahu. Pengolahan limbah cair industri tahu yang sederhana dengan biaya yang murah dan efisien sangat dibutuhkan oleh pengrajin tahu. Salah satu cara yang dapat digunakan untuk mengatasi masalah tersebut adalah dengan menggunakan metode arang aktif. Ampas kopi adalah bahan yang murah dan mudah didapatkan serta dapat digunakan untuk mengurangi kadar amonia, nitrit dan nitrat dalam limbah cair industri tahu. Ampas kopi termasuk bahan organik yang dapat dibuat menjadi arang aktif untuk digunakan sebagai adsorben atau bahan penyerap (Sugiharto, 1987). Bahan baku yang berasal dari bahan organik dapat dibuat menjadi arang aktif karena bahan baku tersebut mengandung karbon. Arang aktif merupakan suatu padatan berpori yang dihasilkan dari bahan yang mengandung karbon dengan pemanasan pada suhu tinggi. Semakin luas permukaan arang aktif maka daya adsorpsinya semakin tinggi (Sembiring dan Sinaga, 2003). Penelitian terdahulu menyebutkan bahwa arang aktif dari ampas kopi mampu menyerap ion besi sampai $99,43 \%$ dan mampu menyerap logam merkuri mencapai 99\% (Lubis dan Nasution, 2002). Pada penelitian ini ampas kopi digunakan sebagai bahan pembuatan arang aktif. Selanjutnya arang aktif tersebut digunakan untuk menurunkan kadar amonia, nitrit, dan nitrat dalam limbah cair industri tahu.

\section{METODE PENELITIAN Bahan dan Alat}

Bahan yang digunakan limbah cair industri tahu, ampas kopi, amonium klorida, seng sulfida, natrium hidroksida, larutan EDTA, reagen Nessler, natrium nitrit, asam sulfanilat, NED dihidroklorida, kalium nitrat, Larutan brucin, asam sulfat pekat, $\mathrm{HCl}, \mathrm{I}_{2}$, $\mathrm{Na}_{2} \mathrm{~S}_{2} \mathrm{O}_{3}$, indikator amilum, dan akuades.

Alat yang digunakan adalah alatalat gelas laboratorium, muffle furnace, desikator, ayakan mekanis 100 mesh, 
kertas saring, neraca analitik, $\mathrm{pH}$ meter, spektrofotometer UV-Visible (shimadzu).

\section{Prosedur Penelitian \\ Pembuatan arang aktif}

Ampas kopi dikeringkan dengan dijemur di bawah sinar matahari kemudian direndam dalam larutan pengaktif $\mathrm{HCl} 0,1 \mathrm{M}$ selama 48 jam dan ditiriskan, kemudian dicuci dengan aquades sampai netral. Ampas kopi yang telah diaktivasi dioven untuk mengurangi kadar airnya terlebih dahulu, selanjutnya bahan tersebut dimasukkan kedalam muffle furnace pada suhu $350^{\circ} \mathrm{C}$ selama 3,5 jam. Setelah proses pengarangan selesai ampas kopi dibiarkan dingin dan disimpan dalam desikator.

\section{Karakterisasi arang aktif Rendemen}

Rendemen arang aktif dihitung dengan cara membandingkan antara bobot bahan baku dengan bobot arang aktif setelah karbonisasi.

Rendemen $(\%)=\frac{b}{a} \times 100 \%$

$\mathrm{a}=$ bobot sampel yang diarangkan $(\mathrm{g})$

$\mathrm{b}=$ bobot arang yang dihasilkan $(\mathrm{g})$

\section{Kadar air}

Arang aktif sebanyak 2 gram dimasukkan ke dalam cawan porselin yang telah diketahui bobotnya. Cawan dimasukkan ke dalam oven pada suhu $105^{\circ} \mathrm{C}$ selama 3 jam kemudian didinginkan dalam desikator dan ditimbang.

Kadar air $=\frac{(a-b)}{a} \times 100 \%$

$\mathrm{a}=$ berat karbon awal $(\mathrm{g})$

$\mathrm{b}=$ berat karbon kering $(\mathrm{g})$

\section{Kadar $a b u$}

Arang aktif sebanyak 2 gram dimasukkan ke dalam cawan yang telah diketahui bobotnya. Cawan dimasukkan ke dalam muffle furnace pada suhu $600^{\circ} \mathrm{C}$ selama 3 jam kemudian didinginkan dalam desikator dan ditimbang.

$$
\begin{aligned}
& \text { Kadar abu }=\frac{a}{b} \times 100 \% \\
& \mathrm{a}=\text { berat abu }(\mathrm{g}) \\
& \mathrm{b}=\text { berat karbon kering awal }(\mathrm{g})
\end{aligned}
$$

\section{Daya serap terhadap iodium}

Arang aktif sebanyak 2 gram dimasukkan ke dalam tempat berwarna gelap dan tertutup. $50 \mathrm{~mL}$ larutan iodium 0,1 N dimasukkan ke dalam wadah kemudian dikocok selama 15 menit lalu disaring. Sebanyak $10 \mathrm{~mL}$ filtrat dititrasi dengan larutan natrium tiosulfat $0,1 \mathrm{~N}$. Jika warna kuning larutan hampir hilang, ditambahkan indikator amilum $1 \%$. Titrasi dilanjutkan sampai warna biru tepat hilang.

Daya serap iod $(\mathrm{mg} / \mathrm{g})=$

$$
\begin{aligned}
& \frac{\left\{10-\frac{(N x V)}{0,1}\right\}}{s} \times 12,69 \times 5 \\
& \mathrm{~V}=\begin{array}{l}
\text { larutan natrium tiosulfat yang } \\
\text { diperlukan }
\end{array} \\
& \mathrm{N}=\begin{array}{l}
\text { normalitas larutan natrium } \\
\text { tiosulfat }
\end{array} \\
& \mathrm{s}= \text { berat karbon }(\mathrm{g}) \\
& 12,69= \text { jumlah iod yang sesuai dengan } \\
& 1 \text { ml larutan natrium tiosulfat } \\
& 0,1 \mathrm{~N} .
\end{aligned}
$$

\section{Penentuan waktu kontak optimum}

Limbah cair industri tahu sebanyak $100 \mathrm{~mL}$ dikontakkan dengan 0,2 gram arang aktif berukuran 100 mesh dengan variasi waktu pengocokan 1,10 , 30, 60, 90, dan 120 menit. Limbah cair industri tahu sebelum dan sesudah dikontakkan dengan arang aktif diukur kadar amonia, nitrit dan nitratnya secara spektrofotometri.

\section{Penentuan pH optimum}

Air limbah industri tahu diambil sebanyak $100 \mathrm{~mL}$ kemudian dikontakkan dengan 0,2 gram arang aktif berukuran 100 mesh pada waktu kontak optimum dan diujikan dengan variasi $\mathrm{pH} 4,5,6,7$, 
8, 9, dan 10. Limbah cair industri tahu sebelum dan sesudah dikontakkan dengan arang aktif diukur kadar amonia, nitrit dan nitratnya secara spektrofotometri.

\section{Perhitungan penurunan kadar amonia, nitrit dan nitrat}

Persen penurunan masing-masing parameter dihitung dengan rumus:

$\%$ penurunan $=\frac{(C o-C 1)}{C o} \times 100 \%$

$\mathrm{Co}=$ konsentrasi awal parameter

$\mathrm{C} 1=$ konsentrasi akhir parameter

\section{HASIL DAN PEMBAHASAN \\ Karakterisasi Arang Aktif}

Arang aktif ampas kopi

dikarakterisasi untuk mengetahui kualitasnya meliputi rendemen, kadar air, kadar abu dan daya serap terhadap iodium. Hasil analisis arang aktif yang diperoleh dapat dilihat pada Tabel 2 .

Tabel 2 menunjukkan bahwa arang aktif dari ampas kopi telah memenuhi standar mutu arang aktif menurut SNI No. 06-3730 (1995). Penetapan rendemen arang aktif bertujuan untuk mengetahui jumlah arang aktif yang dihasilkan setelah melalui proses karbonisasi (Pujiarti dan Gentur, 2005). Jumlah minimum maupun maksimum untuk rendemen setelah melalui proses karbonisasi tidak ditentukan dalam SNI.

Tabel 2. Hasil analisis arang aktif

\begin{tabular}{lcc}
\hline Parameter & Hasil Analisis & $\begin{array}{c}\text { Syarat mutu arang aktif } \\
\text { SNI No. 06-3730-1995 }\end{array}$ \\
\hline Rendemen & $14,56 \%$ & - \\
Kadar Air & $3,29 \%$ & Maksimal $15 \%$ \\
Kadar Abu & $1,37 \%$ & Maksimal $2,5 \%$ \\
Daya Serap Terhadap Iodium & $750,245 \mathrm{mg} / \mathrm{g}$ & Minimal $750 \mathrm{mg} / \mathrm{g}$
\end{tabular}

Penetapan kadar air bertujuan untuk mengetahui sifat higroskopis arang aktif. Kadar air yang diperoleh dari hasil penelitian relatif kecil. Hal ini menunjukkan bahwa kandungan air terikat bahan baku yang dikarbonisasi lebih dahulu keluar sebelum diaktivasi (Pujiarti dan Gentur, 2005). Kadar air yang tinggi dapat menurunkan mutu arang aktif karena dapat mengurangi daya serap terhadap gas atau cairan. Halangan molekul-molekul lain untuk masuk semakin besar dengan semakin besarnya molekul air di dalam karbon aktif (Sutawati dalam Sari, 2007).

Penetapan kadar abu arang aktif bertujuan untuk mengetahui kandungan oksida logam dalam arang aktif. Kadar abu yang tinggi dapat menurunkan mutu arang aktif karena semakin tinggi kadar abu maka semakin banyak pula kandungan bahan anorganik yang terdapat dalam bahan tinggi (Pujiarti dan Gentur, 2005). Kadar abu yang dihasilkan pada penelitian ini telah memenuhi standar mutu arang aktif.

Uji iod merupakan parameter untuk mengetahui kemampuan arang aktif dalam menyerap molekul-molekul dengan berat molekul kecil dan zat dalam fasa cair. Semakin tinggi angka iod maka semakin baik arang aktif dalam menyerap molekul yang kecil atau zat dalam fasa cair (Cheremissinoff, 1987). Daya serap arang aktif terhadap iodium yang dihasilkan pada penelitian ini sebesar 
$750,245 \mathrm{mg} / \mathrm{g}$. Daya serap iodium arang aktif ampas kopi telah memenuhi batas minimum syarat mutu arang aktif.

\section{Penentuan Waktu Kontak Optimum Arang Aktif dari Ampas Kopi terhadap Penurunan Kadar Amonia, Nitrit, dan Nitrat Limbah Industri Cair Tahu}

Waktu kontak optimum merupakan waktu pengocokan campuran arang aktif dengan limbah cair tahu, dimana terjadi penurunan kadar amonia, nitrit, dan nitrat pada limbah cair industri tahu paling besar. Pengocokan dimaksudkan untuk memberi kesempatan pada partikel arang aktif untuk bersinggungan dengan senyawa serapan (Sembiring dan Sinaga, 2003). Adsorpsi amonia, nitrit dan nitrat limbah cair industri tahu oleh arang aktif dari ampas kopi pada variasi waktu kontak 1, 10, 30, 45, 60, 90, 120 menit mencapai optimum pada waktu kontak 30 menit seperti ditunjukkan pada Gambar 1.

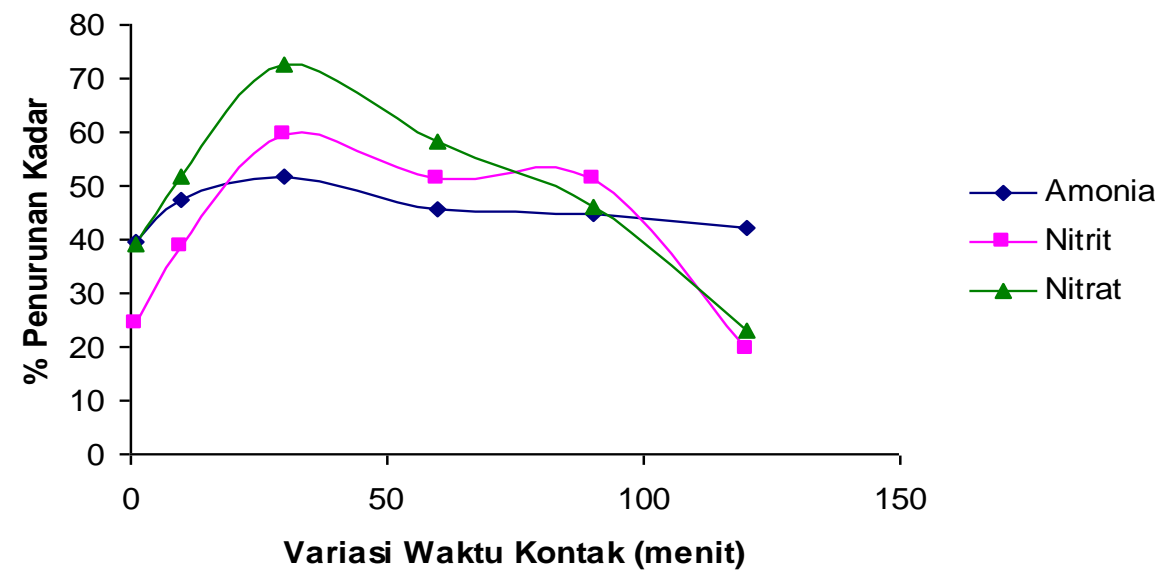

Gambar 1. Kurva Penentuan Waktu Kontak Optimum Arang Aktif dari Ampas Kopi terhadap Penurunan Kadar Amonia, Nitrit dan Nitrat Limbah Cair Industri Tahu

Gambar 1 menunjukkan bahwa penyerapan oleh arang aktif dengan ukuran partikel 100 mesh mencapai optimum pada waktu kontak 30 menit. Pada waktu kontak 1-30 menit terjadi penurunan kadar amonia, nitrit dan nitrat yang signifikan. Arang yang sudah diaktifkan permukaannya menjadi lebih luas karena telah bebas dari deposit hidrokarbon dan pori-porinya telah terbuka sehingga mampu mengadsorpsi amonia, nitrit dan nitrat (Lubis dan Nasution, 2002). Pada waktu kontak 60 menit terjadi penurunan nilai adsorpsi. Hal ini disebabkan pori-pori arang aktif telah jenuh atau telah tertutup oleh adsorbat sehingga arang aktif tidak mampu lagi menyerap adsorbat.

Penurunan nilai adsorpsi terjadi secara terus menerus pada waktu kontak 90 menit dan 120 menit. Penurunan nilai adsorpsi yang terjadi secara terus menerus setelah mencapai waktu kontak optimum menunjukkan bahwa arang aktif ampas kopi mengalami desorpsi yaitu melepaskan kembali sampel limbah yang telah diadsorpsi karena arang aktif ampas kopi telah jenuh oleh sampel limbah cair tahu. Apabila waktu pengocokan diperpanjang, maka arang aktif yang telah menyerap amonia, nitrit, dan nitrat secara optimum akan dilepas kembali ke 
dalam larutan (limbah cair tahu). Hal ini disebabkan arang aktif mempunyai kapasitas serap maksimum dalam menyerap amonia, nitrit dan nitrat.

Adsorpsi yang terjadi pada arang aktif dengan limbah cair tahu merupakan adsorpsi fisik. Peristiwa adsorpsi pada arang aktif terjadi karena adanya gaya Van der Walls yaitu gaya tarik-menarik intermolekuler antara molekul padatan dengan solut yang diadsorpsi lebih besar daripada gaya tarik-menarik sesama solut itu sendiri di dalam larutan, maka solut akan terkonsentrasi pada permukaan padatan. Adsorpsi jenis ini tidak bersifat site spesific, dimana molekul yang teradsorpsi bebas untuk menutupi seluruh permukaan padatan (Adamsons, 1976).

\section{Penentuan pH Optimum Arang Aktif dari Ampas Kopi terhadap Penurunan Kadar Amonia, Nitrit, dan Nitrat Limbah Cair Industri Tahu}

Kondisi pH yang baik adalah kondisi $\mathrm{pH}$ dimana masih memungkinkan kehidupan biologis di dalam air berjalan baik (Sugiharto, 1987). Nilai $\mathrm{pH}$ ini penting untuk dipertimbangkan karena dapat mempengaruhi proses dan kecepatan reaksi kimia di dalam air (Karim, 2007). Air limbah dengan pH yang tidak netral akan menyulitkan proses biologis.

Penentuan $\mathrm{pH}$ optimum dilakukan pada berbagai variasi $\mathrm{pH}$ limbah cair industri tahu yaitu $\mathrm{pH} 4,5,6,7,8,9$ dan 10 dengan menggunakan waktu kontak optimum 30 menit. Pengaturan $\mathrm{pH}$ asam dilakukan dengan cara penambahan larutan $\mathrm{NaOH} 0,1 \mathrm{~N}$ dan pengaturan $\mathrm{pH}$ basa dilakukan dengan cara penambahan larutan $\mathrm{HCl} \mathrm{0,1} \mathrm{N.}$

Analisis kadar amonia, nitrit dan nitrat limbah cair industri tahu dilakukan dengan metode yang berbeda-beda. Analisis amonia dalam limbah cair tahu ditentukan menggunakan metode Nessler. Metode Nessler terdiri dari suatu analisa kimiawi dengan menggunakan alat spektrofotometer. Reagen Nessler $\mathrm{K}_{2} \mathrm{HgI}_{4}$ bereaksi dengan $\mathrm{NH}_{3}$ dalam larutan yang bersifat basa, sesuai dengan reaksi berikut.

$$
\begin{aligned}
& 2 \mathrm{~K}_{2} \mathrm{HgI}_{4}+\mathrm{NH}_{3}+3 \mathrm{KOH} \leftrightarrow \\
& \mathrm{IHgNHHgOH}+7 \mathrm{KI}+2 \mathrm{H}_{2} \mathrm{O}
\end{aligned}
$$

Reaksi menghasilkan larutan berwarna kuning-coklat yang mengikuti hukum Lambert-Beer. Intensitas warna yang terjadi berbanding lurus dengan konsentrasi $\mathrm{NH}_{3}$ yang ada dalam sampel, yang kemudian ditentukan secara spektrofotometris. Penambahkan larutan basa dan $\mathrm{ZnSO}_{4}$ pada analisa Nessler berfungsi untuk mencegah gangguan ion $\mathrm{Ca}, \mathrm{Mg}, \mathrm{Fe}$ dan $\mathrm{Sn}$ yang dapat menimbulkan kekeruhan.

Analisis kadar nitrit dan nitrat ditentukan secara spektrofotometri. Nitrit berkaitan dengan hasil reaksi antara diazo asam sulfanilik dan N- (1-naftil)etilendiamin dihidriklorida (NED Dihidroklorida), membentuk larutan yang berwarna merah muda. Kekuatan warna tersebut mengikuti hukum Lambert-Beer. Sedangkan Nitrat berkaitan dengan hasil reaksi antara brucin dengan $\mathrm{H}_{2} \mathrm{SO}_{4}$ pekat membentuk warna kuning dan absorbansinya diukur dengan spektrofotometer Visible pada panjang gelombang maksimum (Alaerts dan Santika, 1974).

Persentase penurunan kadar amonia, nitrit dan nitrat limbah cair industri tahu oleh arang aktif dari ampas kopi terhadap variasi $\mathrm{pH}$ pada waktu kontak optimum 30 menit dapat dilihat pada Gambar 2. 


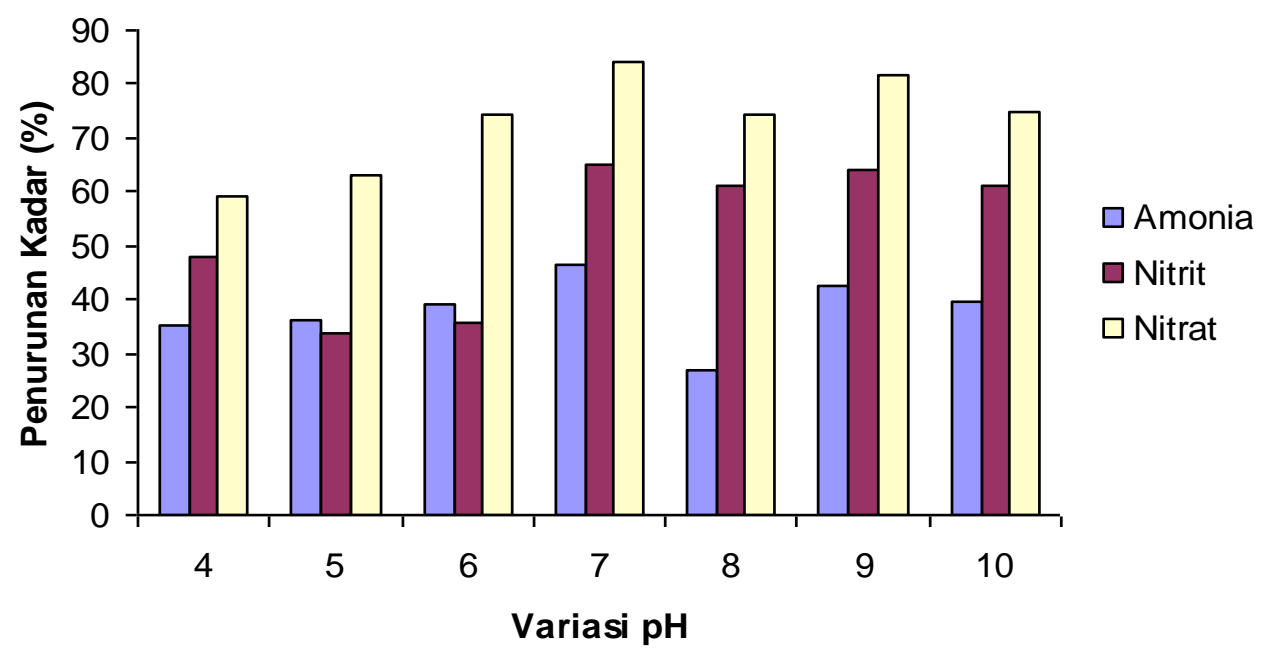

Gambar 2. Grafik Penentuan pH Optimum Arang Aktif dari Ampas Kopi terhadap Penurunan Kadar Amonia, Nitrit dan Nitrat Limbah Cair Industri Tahu

Gambar 2 menunjukkan bahwa persentase penurunan kadar amonia, nitrit dan nitrat limbah cair industri tahu menggunakan arang aktif dari ampas kopi mencapai optimum pada $\mathrm{pH} 7$. Pada proses penurunan kadar amonia, nitrit dan nitrat selain terdapat proses adsorpsi, persentase total penurunan kadar amonia, nitrit dan nitrat dengan menggunakan adsorben arang aktif dari ampas kopi yang diperoleh juga dibantu oleh proses dekomposisi bahan organik oleh mikroorganisme. $\quad \mathrm{pH}$ netral memungkinkan kehidupan biologis limbah berjalan dengan baik, dibandingkan pada $\mathrm{pH}$ asam maupun basa sehingga memungkinkan proses dekomposisi bahan organik limbah berjalan dengan baik. Hal tersebut menyebabkan bahan organik yang terlarut dalam limbah menjadi berkurang. Mikroorganisme juga memanfaatkan bahan organik untuk pertumbuhannya. Mikroorganisme membutuhkan nutrisi khususnya protein dan karbohidrat untuk tumbuh. Bahan organik merupakan sumber energi dan bahan makanan bagi mikroorganisme yang terdapat dalam limbah karena bahan organik menyediakan karbon sebagai sumber energi untuk tumbuh sehingga pada $\mathrm{pH}$ netral diperoleh persentase penurunan kadar amonia, nitrit dan nitrat yang optimum.

Penurunan kadar amonia, nitrit dan nitrat limbah cair industri tahu dilakukan pada waktu kontak optimum 30 menit dan $\mathrm{pH}$ optimum 7. Persentase penurunan kadar amonia, nitrit dan nitrat dilakukan tiga kali perlakuan pada sampel yang berbeda dan masing-masing dianalisis secara duplo. Data hasil penurunan kadar amonia, nitrit dan nitrat dapat dilihat pada Tabel 3, 4 dan 5 . 
Tabel 3. Persen penurunan kadar amonia pada waktu kontak optimum dan pH optimum 7. Konsentrasi amonia limbah awal $=34,4137 \mathrm{mg} / \mathrm{L}$

\begin{tabular}{cccccc}
\hline $\begin{array}{c}\text { Ukuran } \\
\text { Partikel }\end{array}$ & $\begin{array}{c}\text { Ulangan 1 } \\
(\mathrm{mg} / \mathrm{L})\end{array}$ & $\begin{array}{c}\text { Ulangan 2 } \\
(\mathrm{mg} / \mathrm{L})\end{array}$ & $\begin{array}{c}\text { Rata-rata } \\
(\mathrm{mg} / \mathrm{L})\end{array}$ & $\begin{array}{c}\% \\
\text { penurunan }\end{array}$ & $\begin{array}{c}\text { \% penurunan } \\
\text { rata-rata }\end{array}$ \\
\hline \multirow{2}{*}{100} & 12,9753 & 13,4359 & 13,2056 & 61,63 & \\
mesh & 12,2169 & 12,1461 & 12,1815 & 64,60 & 64,69 \\
& 11,2035 & 10,9342 & 11,0688 & 67,84 & \\
\hline
\end{tabular}

Tabel 4. Persen penurunan kadar nitrit pada waktu kontak optimum 30 menit dan $\mathrm{pH}$ optimum 7. Konsentrasi nitrit limbah awal = 7,6811 mg/L

\begin{tabular}{ccccccc}
\hline $\begin{array}{c}\text { Ukuran } \\
\text { Partikel }\end{array}$ & $\begin{array}{c}\text { Ulangan 1 } \\
(\mathrm{mg} / \mathrm{L})\end{array}$ & $\begin{array}{c}\text { Ulangan 2 } \\
(\mathrm{mg} / \mathrm{L})\end{array}$ & $\begin{array}{c}\text { Rata- rata } \\
(\mathrm{mg} / \mathrm{L})\end{array}$ & $\begin{array}{c}\% \\
\text { penurunan }\end{array}$ & $\begin{array}{l}\text { \% penurunan } \\
\text { rata-rata }\end{array}$ \\
\hline \multirow{3}{*}{100 mesh } & 3,7593 & 3,6629 & 3,7711 & 51,69 & \\
& 3,6701 & 3,6629 & 3,6665 & 52,27 & 52,35 \\
& 3,7039 & 3,6547 & 3,6793 & 52,09 & \\
\hline
\end{tabular}

Tabel 5. Persen penurunan kadar nitrat pada waktu kontak optimum 30 menit dan $\mathrm{pH}$ optimum 7. Konsentrasi nitrat limbah awal $=474,3058 \mathrm{mg} / \mathrm{L}$

\begin{tabular}{cccccc}
\hline $\begin{array}{c}\text { Ukuran } \\
\text { Partikel }\end{array}$ & $\begin{array}{c}\text { Ulangan 1 } \\
(\mathrm{mg} / \mathrm{L})\end{array}$ & $\begin{array}{c}\text { Ulangan 2 } \\
(\mathrm{mg} / \mathrm{L})\end{array}$ & $\begin{array}{c}\text { Rata-rata } \\
(\mathrm{mg} / \mathrm{L})\end{array}$ & $\begin{array}{c}\% \\
\text { penurunan }\end{array}$ & $\begin{array}{c}\text { \% penurunan } \\
\text { rata-rata }\end{array}$ \\
\hline \multirow{3}{*}{100 mesh } & 37,1654 & 51,3798 & 44,2726 & 90,67 & \\
& 67,5776 & 71,5444 & 69,5610 & 85,33 & 86,40 \\
& 74,1889 & 85,0977 & 79,6433 & 83,21 & \\
\hline
\end{tabular}

Persentase penurunan kadar amonia, nitrit dan nitrat limbah cair industri tahu menggunakan adsorben arang aktif dari ampas kopi yang diperoleh berdasarkan hasil perhitungan yaitu kadar amonia sebesar $64,69 \%$, nitrit sebesar 52,35\%, dan nitrat sebesar $86,40 \%$. Persentase penurunan kadar nitrit yang diperoleh cukup kecil dibandingkan persentase kadar amonia dan nitrat limbah cair industri tahu, hal tersebut disebabkan nitrit merupakan senyawa yang tidak stabil. Nitrit merupakan tahap intermediet (transisi) dalam dekomposisi biologis senyawa organik yang mengandung nitrogen. Nitrit dapat langsung berubah menjadi nitrat dengan adanya oksigen yang terlarut dalam limbah cair industri tahu. Sedangkan persentase penurunan kadar nitrat pada limbah cair industri tahu yang diperoleh cukup tinggi dibandingkan dengan persentase penurunan kadar amonia dan nitrit. Bahan organik berupa protein yang terdapat dalam limbah cair industri tahu terdekomposisi menjadi amonia dengan bantuan mikroorganisme pengurai yang terdapat dalam limbah cair industri tahu. Pada kondisi aerobik amonia teroksidasi menjadi nitrit, kemudian nitrit dioksidasi lagi menjadi nitrat sehingga senyawa kimia yang paling banyak ditemukan adalah nitrat. Pada proses adsorpsi, nitrat paling banyak teradsorpsi pada pori-pori arang aktif ampas kopi dibandingkan dengan amonia dan nitrit sehingga persentase penurunan kadar nitrat yang diperoleh cukup tinggi.

Salah satu langkah yang dapat dilakukan agar dapat diperoleh persentase penurunan kadar amonia, nitrit, dan nitrat 
yang tinggi diantaranya dilakukan aerasi terhadap limbah cair industri tahu agar bakteri nitrifikasi dapat tumbuh dengan baik. Mikroba nitrifikasi adalah mikroba aerobik, oleh karena itu ketersediaan oksigen terlarut sangat dibutuhkan untuk menunjang kehidupan bakteri nitrifikasi (Jenie dan Rahayu, 1993). Semakin banyak bakteri yang terdapat dalam limbah semakin banyak pula material organik dalam limbah cair industri tahu yang terdekomposisi sehingga dapat diperoleh persentase penurunan kadar amonia, nitrit dan nitrat yang tinggi.

\section{KESIMPULAN}

Berdasarkan hasil penelitian yang diperoleh maka dapat diambil kesimpulan sebagai berikut :

1. Hasil Analisis arang aktif meliputi rendemen 14,56\%; kadar air 3,29\%; kadar abu $1,37 \%$ dan daya serap terhadap iodium $750,245 \mathrm{mg} / \mathrm{g}$.

2. Waktu kontak dan $\mathrm{pH}$ optimum penurunan kadar amonia, nitrit, dan nitrat limbah cair industri tahu menggunakan arang aktif dari ampas kopi dicapai pada waktu kontak 30 menit dan $\mathrm{pH} 7$.

3. Persentase penurunan kadar amonia, nitrit dan nitrat limbah cair industri tahu menggunakan arang aktif dari ampas kopi pada waktu kontak dan pH optimum yaitu kadar amonia 64,69 \%; kadar nitrit 52,35\%; dan kadar nitrat 86,40\%.

\section{UCAPAN TERIMAKASIH}

Terimakasih kami sampaikan kepada Dekan Fakultas Sains dan Teknik Universitas Jenderal Soedirman atas kesempatan yang diberikan kepada penulis untuk melakukan penelitian dari sumber dana DIPA Fakultas Sains dan Teknik.

\section{DAFTAR PUSTAKA}

Adamsons, W.A. 1976. Physical Chemistry of Surface. Interscience. New York.

Alaerts, G dan S. S. Santika. 1984. Metode Penelitian Air. Usaha Nasional. Surabaya.

Bahri, S. 2006. Pemanfaatan Tumbuhan Air (Azolla) untuk Pengolahan Limbah Cair Industri Tahu di Desa Bandarjaya Kecamatan Terbanggi Besar Lampung Tengah. http://library.unila.ac.id/digilib/go .php?id=laptunilapp-gdl-res2006-sonnywedia-287. Diakses Tanggal 2 februari 2008.

Cheremisinoff dan A. C. Moressi. 1978. Carbon Adsorption Handbook. An Arbor Science Publisher Inc. Michigan.

Jenie, B. S. L. dan W. P. Rahayu. 1990. Penanganan Limbah Industri Pangan. Kanisius. Yogyakarta.

Karim, M Y. 2007. Pengaruh salinitas dan Bobot terhadap Konsumsi Kepiting Bakau (Scylla serrata forsskal). Jurnal Sains dan Teknologi. Fakultas Perikanan dan Kelautan. UNHAS. (on-line).

Lubis, S. dan R. Nasution. 2002. Pemanfaatan Limbah Bubuk Kopi sebagai Adsorben pada Penurunan Kadar Besi (Fe anorganik) dalam Air Minum. Jurnal Natural, Volume 2, No. 2, September 2002:12-16.

Nurhasan, A. dan B. B. Pramudyanto. 1997. Pengolahan Air Buangan Tahu. Yayasan Bina Karta Lestari 
dan Wahana Lingkungan Hidup Indonesia, Semarang.

Pelczar, M.J. dan E.C.S. Chan. 1996. Dasar-Dasar Mikrobiologi. UI Press. Jakarta.

Pujiarti. R dan J. P. Gentur Sutapa. 2005. Mutu Arang Aktif dari Limbah Kayu Mahoni (Switenia macrophylla King). Jurnal Ilmu dan Teknologi Kayu tropis Vol 3. No. 2. Universitas Gadjah Mada. Yogyakarta. (on-line).

Sari, D M. 2007. Pemanfaatan Ampas Tebu sebagai Bahan Arang Aktif untuk Menurunkan Kadar BOD, COD, TSS Limbah Cair Industri Tekstil. Skripsi. Fakultas Sains dan Teknik Universitas Jenderal Soedirman Purwokerto (tidak dipublikasikan).
Sembiring, M. T. dan T. S. Sinaga. 2003. Arang Aktif (Pengenalan dan Proses Pembuatannya). http://library.usu.ac.id/download/f t/industri-meilita.pdf. Diakses Tanggal 31 Desember 2007.

Standar Nasional Indonesia (SNI) No. 06-3730. 1995. Syarat Mutu Arang Aktif Indonesia. Departemen Perindustrian. Jakarta.

Sugiharto. $1987 . \quad$ Dasar-Dasar Pengolahan Air Limbah. UI Press. Jakarta. 